\title{
PENGARUH PROGRAM KELUARGA HARAPAN (PKH) TERHADAP PENANGGULANGAN KEMISKINAN DI KECAMATAN WOYLA KABUPATEN ACEH BARAT
}

\author{
Nani Marwida ${ }^{1)}$ dan Mahrizal ${ }^{2)}$ \\ 1) Prodi Ekonomi Pembangun Fakultas Ekonomi Universitas Teuku Umar \\ ${ }^{2)}$ Fakultas Ekonomi Pembangunan Universitas Teuku Umar \\ Email: nanimarwida09@gmail.com dan mahrizal@utu.ac.id
}

\begin{abstract}
Destitution is a fundamental problem faced by all countries, particularly developing countries like Indonesia. Destitution is a complex problem, so special attention is needed to overcome it. One of the poverty reduction efforts undertaken by the Government of Indonesia is through the Family Hope Program (PKH), which began to emerge in 2007.This research aim to find out and analyze the effect of the Family Hope Program on poverty alleviation in Woyla District, which is one of the areas that received assistance from the Family Hope Program. In this study using quantitative descriptive research methods. The object of this research is the Family Hope Program KPM in Woyla District. The data used are sourced from primary data in the form of answers to questionnaires, observations and secondary data from the government's official website and the secretariat archives of Woyla District. Methods of data analysis carried out in the form of normality test and simple linear regression. The results of the analysis with the help of the SPSS 20 program indicate that there is a strong relationship between the variables of the Family Hope Program (PKH) and the poverty alleviation variable with a correlation coefficient of 0.601 and a determinant coefficient of 0.361. This means that the Family Hope Program (PKH) has a positive and significant effect on destitution reduction in Woyla District, this means that if the Family Hope Program increases, poverty reduction will also increase.
\end{abstract}

Keywords: Family Hope Program, PKH, Poverty Reduction.

1. Pendahuluan

Indonesia merupakan negara kepulauan dengan keberagaman suku. Indonesia mempunyai sekitar 17.504 pulau, masyarakat Indonesia terbagi menjadi sekitar 300 suku seperti suku Batak, Jawa, Cina, Dayak, dsb. Indonesia juga memiliki jumlah penduduk yang tinggi, berdasarkan Badan Pusat Statistik (2020), pada September 2020 penduduk Indonesia berjumlah 270,20 juta jiwa. Dengan jumlah tersebut Indonesia berada pada posisi keempat negara dengan populasi penduduk terpadat di dunia. Selain itu, Indonesia juga mengalami pertumbuhan penduduk yang cepat, dari hasil Sensus Penduduk pada September 2020 diketahui bahwa terjadi peningkatan jumlah penduduk sebesar 32,56 juta jiwa dibanding hasil Sensus Penduduk pada tahun 2010. Laju Pertumbuhan Penduduk pertahun selama periode 2010-2020 rata-rata adalah 1,25 persen, melambat dari periode tahun 2000-2010 yang berjumlah 1,49 persen.
Pesatnya pertumbuhan penduduk yang terjadi di Indonesia, menyebabkan terjadinya beberapa permasalahan, salah satunya adalah masalah ekonomi. Menurut teori Malthus, pesatnya pertumbuhan penduduk dalam sebuah negara akan memperparah tingkat kemiskinan negara tersebut. (Todaro, 2006: 329). Menurut Suparlan, kemiskinan dapat dideskripsikan sebagai rendahnya tingkat standar kehidupan seseorang, yaitu terdapat sejumlah atau sekelompok orang yang memiliki materi kurang dari standar yang berlaku di masyarakat secara umum. Para ahli ilmu sosial berpendapat bahwa sistem ekonomi yang berlaku di masyarakat menjadi penyebab utama kemiskinan. Namun, sebagian ahli juga menyebutkan bahwa kemiskinan terjadi sebagai hasil dari interaksi yang melihat hampir segala aspek kehidupan manusia, tidak hanya terpaku pada sistem ekonomi saja. (Mubyarto, 2010).

Kemiskinan merupakan permasalahan global dimana hampir semua negara mengalami permasalahan tersebut. Menurut 
Todaro dan Smith (2006: 232) ada dua faktor utama yang menentukan tinggi atau rendahnya kemiskinan di suatu negara, yaitu jumlah ratarata pendapatan nasional dan tingkat ketimpangan distribusi pendapatan. Meskipun suatu negara mencapai tingkat pendapatan perkapita yang tinggi, selama masih terdapat ketimpangan pada distribusi pendapatan, maka tingkat kemiskinan yang terjadi akan tetap tinggi. Begitupun sebaliknya, meskipun distribusi pendapatan pada suatu negara sudah merata, tetapi tingkat pendapatan perkapitanya rendah, maka kemiskinan juga akan semakin meningkat.

Di Indonesia sendiri pemerintah sudah melakukan berbagai upaya untuk menanggulangi kemiskinan, akan tetapi masih belum maksimal. Hal ini terlihat dari tingkat kemiskinan Indonesia yang tidak menunjukkan penurunan yang signifikan, meskipun berbagai upaya penanggulangan kemiskinan telah dicanangkan dari tahun ke tahun. Badan Pusat Statistik Indonesia (2020) mencatat pada September 2020 penduduk miskin Indonesia berjumlah 27,55 juta jiwa atau sebesar 10,19 persen, bertambah 1,13 juta jiwa atau 0,41 persen terhadap Maret 2020. Menyadari permasalahan tersebut, sebagai upaya mempercepat pengentasan kemiskinan pemerintah Indonesia membentuk program khusus yang membantu masyarakat bersangkutan secara langsung. Salah satunya yaitu Program Keluarga Harapan (PKH) yang berjalan semenjak tahun 2007 di Indonesia. (Kementerian Sosial, 2019).

Tujuan $\mathrm{PKH}$ diantaranya adalah mengurangi tingkat kemiskinan dan kesenjangan, mengurangi tanggungan pengeluaran rumah tangga miskin serta membantu meningkatkan pendapatan, menciptakan kemandirian dan perubahan perilaku KPM dalam mengakses fasilitas pendidikan, kesehatan, juga kesejahteraan sosial sehingga taraf hidup KPM akan meningkat. (pkh.kemensos.go.id, 2019).

Program Keluarga Harapan sudah dijalankan di berbagai wilayah di Indonesia sejak tahun 2007. Kabupaten Aceh Barat merupakan salah satu wilayah yang menerima bantuan PKH. Menurut Sekdakab Aceh Barat Marhaban SE, penduduk miskin Kabupaten Aceh Barat pada tahun 2020 berjumlah 39.060 jiwa atau sebesar 18,34 persen, turun sebanyak 230 jiwa atau 2,39 persen dari 39.290 jiwa atau 18,79 persen pada tahun 2019. (acehbaratkab.go.id, 2021). Berikut ini disajikan grafik data persentase kemiskinan di Kabupaten Aceh Barat.
Grafik 1

Presentase Kemiskinan Kabupaten Aceh Barat Tahun 2016-2020

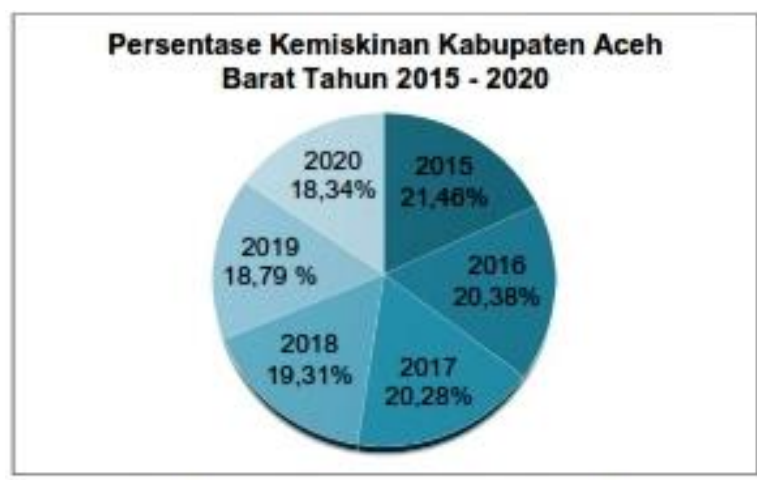

Sumber Data : BPS Kabupaten Aceh Barat (2020)

Meskipun terus mengalami penurunan, namun tingkat kemiskinan di Kabupaten Aceh Barat masih tergolong tinggi, maka tak heran jika jumlah penerima $\mathrm{PKH}$ di Kabupaten Aceh Barat juga besar. Berdasarkan website resmi Pemerintah Kabupaten Aceh Barat, pada tahun 2020 penerima bantuan $\mathrm{PKH}$ Aceh Barat berjumlah 10.270 KK yang tersebar di 12 kecamatan. (dinsos.acehprov.go.id, 2020)

Kecamatan Woyla merupakan salah satu kecamatan dengan jumlah KPM PKH terbanyak di Kabupaten Aceh Barat. Menurut data pada Sekretariat Kecamatan Woyla, terdapat sebanyak 1118 KPM PKH pada tahun 2020. Akan tetapi, dari hasil pengamatan di lapangan penerapan Program Keluarga Harapan di Kecamatan Woyla kurang efektif. Tampak semua kendala yang dihadapi, seperti penerima bantuan yang tidak tepat sasaran dan pemanfaatan bantuan yang tidak sejalan dengan tujuan $\mathrm{PKH}$.

\section{Literatur Review \\ Program Keluarga Harapan}

Program Keluarga Harapan (PKH) ialah salah satu bentuk bantuan kluster pertama dalam upaya penyelesaian masalah kemiskinan di Indonesia. Program ini membantu Keluarga Miskin (KM) dengan memberi bantuan tunai apabila keluarga tersebut memenuhi persyaratan terkait pendidikan dan kesehatan. Tujuan PKH secara umum ialah menciptakan sumber daya manusia (SDM) yang bermutu, mengubah perilaku, pendapat serta pola pikir rumah tangga sangat miskin (RTSM) sehingga mampu mengakses pendidikan dan kesehatan yang lebih baik, dengan harapan dapat memutus rantai kemiskinan (Direktorat Jaminan Sosial, Direktorat Jenderal Perlindungan dan Jaminan Sosial Kementerian RI, 2012). 
Program PKH dibentuk oleh Kementerian Sosial RI berdasarkan Keputusan Menteri Koordinator Bidang Kesejahteraan Rakyat selaku Ketua Tim Koordinasi Penanggulangan Kemiskinan No: 31/KEP/MENKO/-ESRA/IX/2007 Tentang "Tim Pengendali Program keluarga Harapan" pada tanggal 21 September 2007. (Kementrian Sosial RI, 2016). Badan Perencanaan dan Pembangunan Nasional (Bappenas) mengeluarkan Program Keluarga Harapan (PKH) pada tahun 2007. (Kementrian Sosial RI, 2016)

Badan

Pembangunan mengeluarkan (PKH) pada tahun 2007. Peraturan Menteri Sosial No. 1 Tahun 2018 Bab 1 ketentuan umum pasal 1 menjelaskan, "Program Keluarga Harapan yang kemudian disebut PKH ialah suatu bentuk program yang memberikan bantuan sosial bersyarat untuk membantu keluarga/seseorang yang miskin serta rentan yang terhimpun pada Data Terpadu Kesejahteraan Sosial (DTKS), diproses oleh pusat Data dan Informasi Kesejahteraan Sosial kemudian ditetapkan menjadi penerima bantuan PKH". Dari pernyataan tersebut dapat disimpulkan bahwa $\mathrm{PKH}$ ialah program pemberian uang tunai untuk keluarga maupun seorang miskin dengan harapan akan mengurangi kemiskinan. Berdasarkan Kementerian Sosial RI (2015: 2), penerima bantuan $\mathrm{PKH}$ ialah keluarga miskin yang di dalamnya terdapat satu maupun beberapa unsur PKH, yaitu: (1) Keluarga yang didalamnya terdapat anak balita, ibu hamil atau ibu nifas; (2) Keluarga yang mempunyai anak usia prasekolah (Kementerian Sosial RI, 2015).

\section{Kemiskinan}

Menurut Alhudori (2017), kemiskinan ialah suatu konteks dimana seorang tidak dapat mencukupi kebutuhan pokok seperti makanan, pakaian, tempat tinggal, kesehatan serta pendidikan. Langkanya alat pemenuh kebutuhan maupun sukarnya akses akan pendidikan dan pekerjaan dapat menjadi penyebab terjadinya kemiskinan.

Terdapat dua sudut pandang definisi kemiskinan, yaitu (Maipita, 2014) :

1. Kemiskinan berdasarkan ukuran kebutuhan hidup layak. Golongan ini memiliki pendapat bahwa kemiskinan muncul ketika kebutuhan pokok tidak terpenuhi. Kemiskinan ini dikenal dengan sebutan kemiskinan absolut.

\section{Kemiskinan berdasarkan tingkat} pendapatan. Pandangan ini beranggapan kemiskinan terbentuk karena penghasilan yang digunakan untuk memenuhi kebutuhan hidup tidak mencukupi.

Sharp et., al, dalam Mulyono (2017), mencoba mengetahui pemicu kemiskinan dari sudut pandang ekonomi. Yaitu : (1) Secara mikro, kemiskinan terjadi akibat perbedaan paradigma kepemilikan sumber daya, dimana sumber daya yang dimiliki penduduk miskin jumlahnya terbatas serta kualitasnya rendah sehingga menimbulkan ketimpangan pada distribusi pendapatan. (2) Kemiskinan terjadi karena ketidaksamaan kualitas SDM. Minimnya kualitas SDM berarti produktivitasnya juga kurang, sehingga tingkat upahnya pun rendah. Perbedaan kualitas SDM dapat disebabkan oleh tingkat pendidikan, diskriminasi, keturunan atau bahkan keberuntungan nasib. (3) Kemiskinan terjadi sebab adanya perbedaan akses terhadap modal.

Penelitian sebelumnya terkait Program Keluarga Harapan oleh Sabinus Beni dan Blasius Manggu yang berjudul Efektivitas Program Keluarga Harapan Terhadap Penanggulangan Kemiskinan di Perbatasan disimpulkan bahwa Program Keluarga Harapan di Kecamatan Jagoi Babang Kabupaten Bengkayang Kalimantan Barat sudah efektif, PKH sangat efektif terutama dilihat dari aspek pendidikan, kesehatan dan perbaikan taraf hidup, dimana pada KPM PKH tingkat putus sekolah anak-anak semakin rendah, keluarga menjadi lebih rajin mengunjungi fasilitas kesehatan, serta kesadaran masyarakat untuk menabung semakin besar. Akan tetapi dalam jangka pendek PKH belum menunjukkan pengaruh yang signifikan terhadap peningkatan kualitas hidup KPM karena output bantuan berwujud investasi SDM usia sekolah (SD, SMP, SMA). Serta belum tersedia program pemberdayaan yang diterapkan untuk mengembangkan hard skill dan soft skill sebagai upaya meningkatkan derajat hidup KPM. Masih banyak masyarakat maupun keluarga miskin yang tidak memperoleh bantuan PKH karena data yang digunakan bersumber dari Basis Data Terpadu Kementerian Sosial tahun 2015, sehingga penduduk miskin diatas tahun 2015 tidak tertampung. Serta belum terlihat kepedulian pemerintah terhadap peningkatan kualitas layanan kesehatan, pendidikan, maupun kondisi pembangunan infrastruktur. 


\section{Metode}

Penelitian ini dilakukan dengan pendekatan survey, dimana pengambilan sampel dari populasi dilakukan dengan cara membagikan kuesioner (daftar pertanyaan) sebagai instrumen pengumpul data yang utama serta umumnya memakai teknik statistik. (Prasetyo dan Miftahuljannah, 2007). Penelitian ini berjenis deskriptif kuantitatif, yakni penelitian yang bermaksud menganalisis atau mendeskripsikan karakteristik sebuah situasi maupun pokok telaah dengan mengumpulkan data, analisis data kuantitatif dan uji statistik. (Edwin dan Usman, 2007).

Penelitian ini dilakukan di 43 desa di Kecamatan Woyla Kabupaten Aceh Barat. Penelitian dimulai dari bulan Mei 2021 hingga bulan Juni 2021. Populasi penelitian ini ialah seluruh KPM bantugan PKH di 43 desa di Kecamatan Woyla Kabupaten Aceh Barat yang berjumlah 1118 KPM. Untuk pengambilan sampel penulis memakai teknik simple random sample (sampel random sederhana), dimana sampel tarik secara acak. Sampel dalam penelitian ini berjumlah $50 \mathrm{KPM}$.

\section{Teknik dan Pengumpulan Data}

Untuk mengumpulkan data, peneliti memakai beberapa metode, yaitu :

1. Observasi, yakni mengumpulkan data/informasi dengan mempelajari fenomena atau fakta-fakta yang berkaitan dengan tingkah laku manusia, dan proses kerja di lapangan secara langsung. (Sugiyono, 2016). Dalam penelitian ini penulis menggunakan observasi berjenis nonpartisipan. Penulis mengamati peserta penerima bantuan $\mathrm{PKH}$ tanpa terlibat langsung dalam kegiatan yang diobservasi.

2. Kuesioner, yakni memberikan sejumlah pertanyaan/pernyataan tertulis kepada responden (Sugiyono, 2016). Daftar pertanyaan ini memakai skala Likert untuk menilai persepsi, perilaku dan pemikiran seseorang atau sekelompok orang terhadap gejala sosial yang diteliti. Dalam penelitian, peneliti telah menetapkan gejala sosial secara khusus, yang kemudian disebut variabel penelitian.

3. Dokumentasi, Teknik dokumentasi ialah mengumpulkan data/informasi melalui dokumen-dokumen, catatan, notulen rapat, buku-buku, majalah, surat kabar, transkrip maupun agenda. Data ini tidak terbatas pada tempat maupun kurun waktu. (Sugiyono, 2013). Metode ini dilakukan untuk memperkaya teori dan pemikiran tentang penelitian yang dilakukan

\section{Teknik Analisis Data}

Analisis data pada penelitian ini menggunakan metode regresi linier sederhana. Metode ini adalah teknik statistik yang dilakukan untuk melihat pengaruh antara satu variabel bebas terhadap variabel terikat. Dalam hal ini, dilakukan untuk melihat pengaruh antara variabel Program Keluarga Harapan (PKH) (X) terhadap variabel Penanggulangan Kemiskinan (Y) di Kecamatan Woyla Kabupaten Aceh Barat.

Model regresi linier sederhana ditujukan untuk memprediksi skala variabel terikat $(Y)$ dengan satu variabel bebas $(X)$. Persamaan pada regresi linier sederhana yaitu

Keterangan :

$$
\mathbf{Y}=a+b x
$$

Y: Penanggulangan Kemiskinan

$\mathrm{X}$ : Program Keluarga Harapan (PKH)

a : Nilai konstanta

b : koefisien regresi

\section{Hasil dan Pembahasan}

Dari indikator-indikator variabel Program Keluarga Harapan (X) yang kemudian dijabarkan dalam bentuk kuesioner yang berjumlah 11 pertanyaan dan didistribusikan kepada 50 responden KPM PKH di Kecamatan Woyla Kabupaten Aceh Barat. Pengujian validitas ini memakai rumus korelasi product moment. Untuk menilai stabilitas alat ukur, maka diterapkan uji reliabilitas dengan rumus Alpha Cronbach.

Tabel 1.

Hasil Uji Normalitas Data

One-Sample Kolmogorov-Smirnov Test

\begin{tabular}{|ll|r|}
\hline & & $\begin{array}{r}\text { Unstandardiz } \\
\text { ed Residual }\end{array}$ \\
\hline N & Mean & 50 \\
Normal Parameters & St. & Std. \\
& Deviation & 2,22576715 \\
Most Extreme & Absolute &, 119 \\
Differences & Positive &, 102 \\
Kolmogorov-Smirnov Z & Negative &,- 119 \\
Asymp. Sig. (2-tailed) & &, 838 \\
\hline
\end{tabular}

a. Test distribution is Normal.

b. Calculated from data.

$$
\text { Sumber: Data Primer diolah (2021) }
$$

Dari uji normalitas yang menggunakan uji Kolmogorov-Smirnov diketahui tingkat signifikansi asymp. Sig (2-tailed) adalah 0,484 ( $p$-value>0.05) yang menandakan residual berdistribusi normal. 


\section{Uji Linearitas}

Untuk melihat korelasi atau hubungan kedua variabel, maka dilakukan perhitungan uji linearitas. Dengan dasar keputusan apabila Sig Deviation from Linearity bernilai > 0.05, maka kedua variabel berkorelasi linear. Dalam penelitian ini diperoleh bahwa hasil uji linearitas diketahui tingkat signifikansi kedua variabel adalah 0,104 (p-value > 0.05) yang menandakan kedua variabel berkorelasi linear.

\section{Uji Heteroskedastisitas}

Uji ini bertujuan untuk mengetahui apakah terjadi perbedaan variance pada residual satu pengamatan terhadap pengamatan lain dalam suatu model regresi. Apabila signifikansi bernilai >0.05 maka tidak berlaku heterokedastisitas, sebaliknya apabila signifikansi. Dari hasil uji heteroskedastisitas, diketahui signifikansinya adalah 1,000, yang mengindikasikan heteroskedastisitas tidak terjadi.

\section{Analisis Korelasi}

Untuk menguji seberapa kuat derajat korelasi atau keterkaitan antara variabel Program Keluarga Harapan (X) terhadap penanggulangan kemiskinan $(\mathrm{Y})$ di Kecamatan Woyla, maka terlebih dahulu dilakukan teknik analisis product moment. Dengan dasar ketentuan apabila signifikansi bernilai 0.05 maka tidak berkorelasi. Dari hasil analisis tersebut diketahui tingkat signifikansi hubungan antara Program Keluarga Harapan dengan penanggulangan kemiskinan adalah senilai 0,000 . Sedangkan nilai Pearson Correlation adalah sebesar 0,601. Hasil tersebut menunjukkan korelasi yang kuat antara Program Keluarga Harapan dengan penanggulangan kemiskinan.

\section{Analisis Regresi}

Regresi linear sederhana dilakukan untuk memprediksi pengaruh antara satu variabel independen $(X)$ terhadap variabel dependen $(Y)$. Model regresi linear sederhana yang diterapkan dapat dilihat dibawah ini:

Tabel 2 Analisis Regresi

\begin{tabular}{|ll|r|r|r|}
\hline \multirow{2}{*}{ Model } & \multicolumn{2}{|c|}{$\begin{array}{r}\text { Unstandardized } \\
\text { Coefficients }\end{array}$} & $\begin{array}{c}\text { Standardized } \\
\text { Coefficients }\end{array}$ \\
\cline { 2 - 5 } & \multicolumn{1}{|c|}{ B } & \multicolumn{1}{c|}{$\begin{array}{c}\text { Etd. } \\
\text { Error }\end{array}$} & \multicolumn{1}{c|}{ Beta } \\
\hline 1 & (Constant) & 19,121 & 3,600 &, 000 \\
& PKH &, 454 &, 087 &, 000 \\
\hline
\end{tabular}

a. Dependent Variable: Kepuasan Kerja

Sumber : Hasil Penelitian, 2021 (Data Diolah)
Pada tabel diatas, diketahui pada Unstandardized Coefficeints bagian B diperoleh persamaan regresi linier berganda pertama yaitu dengan rumus berikut :

Nilai konstanta $a=19,121$, berarti apabila variabel Program Keluarga Harapan (X) tidak berubah (nilai $X=0$ ), maka nilai variabel Penanggulangan Kemiskinan $(Y)$ adalah sebesar 19,121. 2. Nilai koefisien regresi Program Keluarga Harapan ialah 0,454. Yang menandakan apabila terjadi peningkatan sebesar $1 \%$ pada variabel Program Keluarga Harapan (X) serta nilai konstanta (a) sama dengan 0 (nol) maka penanggulangan kemiskinan $(Y)$ meningkat sebesar 0,454. Ini mengindikasikan bahwa variabel Program Keluarga Harapan berkontribusi positif kepada penanggulangan kemiskinan.

\section{Pengujian Hiptesis}

Penerapan uji t bertujuan untuk melihat adakah pengaruh dari model regresi linier sederhana pada variabel bebas terhadap variabel terikat, hasil uji ini dapat perhatian pada Tabel 5 diatas. Variabel bebas dapat dinyatakan memengaruhi variabel terikat jika signifikansinya. Variabel $X$ mempunyai koefisien regresi sebesar 0,454 dengan taraf signifikansi sebesar 0,000 ( $p$ value $<0.05$ ), sehingga hipotesis $\mathrm{Ha}$ diterima dan hipotesis $\mathrm{HO}$ ditolak. Artinya variabel $(\mathrm{X})$ Program Keluarga Harapan (PKH) berpengaruh terhadap variabel (Y) Penanggulangan kemiskinan.

\section{Bahasan}

Pembahasan Dengan bantuan program SPSS 20, diketahui taraf signifikansi variabel $(X)$ Program Keluarga Harapan senilai 0,000 serta nilai koefisien regresi sebesar 0,454 yang berarti PKH memberi pengaruh yang positif dan signifikan kepada penanggulangan kemiskinan. Berdasarkan hasil uji t, diperoleh taraf signifikansi senilai 0,000 berarti nilai signifikansi p-value

\section{Kesimpulan}

1. Program Keluarga Harapan dapat berkontribusi pada penanggulangan kemiskinan apabila dilaksanakan sesuai ketetapan $\mathrm{PKH}$, serta KPM $\mathrm{PKH}$ memahami kewajiban, hak dan tujuan dari PKH sendiri. Belum optimalnya hasil yang diberikan selama ini merupakan akibat dari program yang belum tepat sasaran, kurangnya sosialisasi mengenai tujuan dan kewajiban peserta $\mathrm{PKH}$, penyalahgunaan

Nani Marwida, Mahrizal | Pengaruh Program Keluarga Harapan... 
dana bantuan maupun kurangnya pengawasan pihak terkait.

2. $\mathrm{PKH}$ memberi pengaruh yang positif dan signifikan terhadap Penanggulangan Kemiskinan di Kecamatan Woyla. Artinya, semakin baik penerapan PKH di Kecamatan Woyla akan semakin baik pula penanggulangan kemiskinan yang terjadi

\section{DAFTAR PUSTAKA}

1. Alhudori,M. (2017). Pengaruh IPM, PDRB dan Jumlah Pengangguran Terhadap Kemiskinan di Provinsi Jambi. Jurnal of Economics and Business, 1(1). 113-124.

2. Badan Pusat Statistik. (2021). Hasil Sensus Penduduk 2020. https://www.bps.go.id [diakses tanggal 24 Mei 2021].

3. Badan Pusat Statistik. (2021). Persentase Penduduk Miskin September 2020 Naik Menjadi 10.19 Persen. https://www.bps.go.id [diakses tanggal 23 Mei 2021]. Beni, S. \& Manggu, B. (2020). Efektivitas Program Keluarga Harapan dalam Penanggulangan Kemiskinan di Perbatasan (Studi Kasus Kecamatan Jagoi Babang Kabupaten Bengkayang Kalimantan Barat). Sosio Konsepsia, 9(2), 162170

4. Dinas Sosial Aceh. (2020). 10.270 KK warga Miskin Penerima PKH di Aceh Barat Terima Bantuan Beras dari Pemerintah. https://dinsos.acehprof.go.id [diakses tanggal 28 Mei 2021].

5. Edwin, M \& Hardius, U. (2007) Proses Penelitian Kuantitatif. Jakarta: Badan Penerbit Fakultas Ekonomi Unversitas Indonesia

6. Ghozali, I. (2009). Aplikasi Analisis Multivariate dengan Program SPSS. Semarang : Badan Penerbit Universitas Diponegoro.

7. Gultom, H., Kindangen, P. \& Kawung, G. M. (2021) Analisis Pengaruh Program Bantuan Pangan Non Tunai (BPNT) dan Program Keluarga Harapan (PKH) Terhadap Kemiskinan di Kabupaten Minahasa Tenggara. Jurnal Pembangunan Ekonomi dan Keuangan Daerah, 21(1), 39-53.

8. Kementerian Sosial RI. (2012). Pedoman Umum Program Keluarga Harapan.
Direktorat Jaminan Sosial. Kementerian Sosial RI. Program Keluarga Harapan 2016.

9. Kementerian Sosial. (2019). Pedoman Pelaksanaan Program Keluarga Harapan (2019th ed.) Kholif, K. I. (2014). Implementasi Program Keluarga Harapan (PKH) dalam Menanggulangi Kemiskinan di Kecamatan Dawarblandong Kabupaten Mojokerto. Jurnal Administrasi Publik,2(4), 709-714

10.Mubyarto. (2010). Membangun Sistem Ekonomi. Yogyakarta : BPPE Mulyono, Edy, S. (2017). Kemiskinan \& Pemberdayaan Masyarakat. Yogyakarta: Penerbit Ombak.

11.Pemerintah Kabupaten Aceh Barat. (2021). Pemkab Laporkan Pertanggungjawaban Pemerintah Kepada DPRK Aceh Barat dalam Rapat Paripurna ke II. https://acehbaratkab.go.id [diakses tanggal 29 Mei 2021].

12.Program Keluarga Harapan. (2019) Apa Itu Program Keluarga Harapan.https://pkh.kemensos.go.id [diakses tanggal 02 Juni 2021].

13.Nasution, S. (2010) Metode Research. Jakarta : PT. Bumi Aksara.

14.Sugiyono. (2013). Metode Penelitian kombinasi (Mixed Methods). Bandung : Alfabeta.

15.Sugiyono. (2014). Metode Penelitian Kuantitatif. Bandung : Alfabeta.

16.Sugiyono. (2016). Metode Penelitian Kuantitatif, Kualitatif, dan R\&D. Cetakan Ke-24 Bandung : Alfabeta.

17. Todaro, Michael.P. \& Smith, Stephen C. (2006). Pembangunan Ekonomi. Edisi Kesembilan. Jakarta: Erlangga

18.Warsidi, A. (2017). Sri Mulyani: Kemiskinan Tantangan Besar dalam Pembangunan. https://nasional.tempo.co [diakses tanggal 23 Mei 2021]. 